\title{
TITLE:
}

\section{ON THE SWARMERS AND THEIR DEVELOPMENT OF ULVA CONGLOBATA KJELLMAN}

$\operatorname{AUTHOR}(\mathrm{S})$ :

Yoshida, Keisei

\section{CITATION:}

Yoshida, Keisei. ON THE SWARMERS AND THEIR DEVELOPMENT OF ULVA CONGLOBATA KJELLMAN. PUBLICATIONS OF THE SETO MARINE BIOLOGICAL LABORATORY 1965, 13(2): $115-124$

ISSUE DATE:

1965-08-30

URL:

http://hdl.handle.net/2433/175400

RIGHT: 


\title{
ON THE SWARMERS AND THEIR DEVELOPMENT OF ULVA CONGLOBATA KJELLMAN ${ }^{123}$
}

\author{
KEISEI YOSHIDA \\ Suma Aquarium of Kobe City, Kobe
}

With Plate XI, 2 Text-figures and 2 Tables

Ulva conglobata is a species of green algae in the family Ulvaceae and grows rather prolifically on the rocky shores in the vicinity of the Seto Marine Biological Laboratory. Fronds reach to $2-4 \mathrm{~cm}$ in height and consist of many lobes which expand in an almost circular mass, looking like a flower of treepeony (Plate XI, 14).

On the life-history of $U$. conglobata, K. Fujiyama (1950) reported that the present species produced two kinds of swarmers, namely zoospores and gametes, both of which were furnished with two cilia. Zoospores and zygotes developed into new fronds of about $1 \mathrm{~cm}$ in height, showing the same developmental processes.

The present writer has carried on cultural experiments of this species and some field observations during a year from 1963 to 1964. He succeeded in obtaining small fronds derived from zoospores. And he found out a few facts in the morphology and the behavior of swarmers different from those reported by K. FuJIYAMA.

\section{Material and Method}

All materials used in the present studies were collected on the rocky shore near the Seto Marine Biological Laboratory at Shirahama, Wakayama Prefecture, Japan. The mature fronds were rinsed carefully with filtered sea-water and one by one put into glass-vessels that were filled with filtered sea-water. Soon after, four ciliated swarmers were liberated from the fertile parts of the fronds. Copulation-tests were tried by means of mixing two drops of water each of which contains swarmers derived from each different thallus. All possible combinations were put to trial. After two days while swarmers fastened on the slide-glasses, being kept in a thermos, those slide-

1) Contributions from the Seto Marine Biological Laboratory, No. 437.

2) Contributions from the Suma Aquarium of Kobe City, No. 51.

Publ. Seto Mar. Biol. Lab., XIII (2), 115-124, 1965. (Article 6) 
glasses were carried to the laboratory of Suma Aquarium in Kobe City. Schreiwer solution* added with Plovasoli solution* modified by S. Suto (1960) at a rate of $5 \mathrm{ml}$ to $1000 \mathrm{ml}$ was used as the culture solution. The culture solution was not renewed in early stage of sporelings. But after sporelings developed into a visible stage, the solution was renewed two times a month and also $\mathrm{CO}_{2}$ gas was blown into the solution two times a day by exhalation. In summer, the temperature of the culture solution was controled to keep always at about $18^{\circ} \mathrm{C}$.

\section{Results}

Field observations: At Shirahama, Ulva conglobata grows on rocky shores of

Table 1. Duration and maturation of Ulva conglobata at Shirahama.

\begin{tabular}{l|c|c|c|c|c|c}
\hline \multirow{2}{*}{ Month } & \multicolumn{2}{|c|}{ Vegetative thalli } & \multicolumn{2}{|c|}{ Mature thalli } & \multicolumn{2}{c|}{ Numbers of cilia } \\
\cline { 2 - 6 } & 1963 & 1964 & 1963 & 1964 & 1963 & 1964 \\
\hline Feb. & + & $*$ & - & $*$ & - & $*$ \\
\hline Mar. & $*$ & $*$ & $*$ & $*$ & $*$ & $*$ \\
\hline Apr. & + & + & + & + & 4 & 4 \\
\hline May & $*$ & $*$ & $*$ & $*$ & $*$ & $*$ \\
\hline Jun. & + & $*$ & + & $*$ & 4 & $*$ \\
\hline Jul. & $*$ & + & $*$ & + & $*$ & - \\
\hline Aug. & + & + & - & + & - & 4 \\
\hline Sep. & + & $*$ & - & $*$ & - & $*$ \\
\hline
\end{tabular}

Table 2. Exposure of Ulva conglobata at $12 \mathrm{th}$,

\begin{tabular}{c|c|c|c}
\hline \multirow{2}{*}{ Date } & \multicolumn{2}{|c}{ The hour exposed by low tide } \\
\hline $\begin{array}{c}\text { 12th } \\
\text { daylight }\end{array}$ & $\begin{array}{c}\text { at the highest } \\
\text { part of the } \\
\text { growing area }\end{array}$ & $\begin{array}{c}\text { at the lowest } \\
\text { part of the } \\
\text { growing area }\end{array}$ & $\begin{array}{c}\text { at the middle } \\
\text { line of the } \\
\text { growing area }\end{array}$ \\
\hline $\begin{array}{c}\text { 14th } \\
\text { eary morning }\end{array}$ & $11: 20$ & $12: 10$ & $(11: 45)$ \\
\hline
\end{tabular}

exposed hours : hours from the time when low tide passes down the middle line

* Modified Plovasoli solution: EDTA-Na $3 \mathrm{~g}, \mathrm{FeCl}_{3} 0.08 \mathrm{~g}, \mathrm{MnCl}_{2} 0.12 \mathrm{~g}, \mathrm{ZnCl}_{2} 0.015 \mathrm{~g}, \mathrm{CoCl}_{2}$ $0.003 \mathrm{~g}, \mathrm{CuSO}_{4} 0.0012 \mathrm{~g}, \mathrm{H}_{3} \mathrm{BO}_{3} 0.6 \mathrm{~g}$; distilled water $1000 \mathrm{ml}$. SCHREIBER solution : $\mathrm{NaNO}_{3}$ $0.1 \mathrm{~g}, \mathrm{Na}_{2} \mathrm{HPO}_{4} 0.02 \mathrm{~g}$; distilled water $500 \mathrm{ml}$, sea-water $1000 \mathrm{ml}$. 
the intertidal zone. At low tide, margins and even lower parts of the fronds are exposed for a while and dry up entirely. The basal parts of them, however, get always wet as they live on the area, where subterranean water or a sewage flows out constantly during exposure. These habitats of this alga here were ever explained by H. UTinomi (1958).

The writer made some field observations of this alga four times at the beginning of February, next at the end of June 1963, and in the middle of April and August 1964. Moreover, in April, August and September 1963, and in July 1964, he brought materials to Kobe from Shirahama. As a consequence, it was confirmed that this alga was prolifical at least in February, April and from June to September, maturing in April and also from July to August (Table 1). The writer was told by Mr. T. Yамамото, who lived at Shirahama, that this species grew in other months. Putting these facts together, $U$. conglobata seemed to grow all the year round in the same area.

How many hours this alga was exposed on rocks, it was surveyed by the writer on the 12 th and 14 th of August 1964. As it was calm on those days, he recorded the hour when the highest part of the growing area of this alga was exposed by low tide and also the hour when that part of the area got wet by high tide. Regarding the lowest part of the growing area of this alga, he recorded the hour when the same phenomenon occurred, too. And he estimated that the middle line of the growing area was submerged or exposed for 6 hrs. 10 mins. in the daytime on the 12th August (Table 2). By means of comparing these records with the "Tide Tables in 1964"*, the tide level of the habitat of this alga was computed precisely. The black spots on the tide curves in Text-fig. 1 show the hours surveyed. Although these surveyed values show some deviations, it may be recognized at least that $U$. conglobata grows on the slope at tide levels from $104 \mathrm{~cm}$ to $124 \mathrm{~cm}$. The hours during exposure on other days are computed on the basis of above-

14th August 1964.

Table 2 (continued)

\begin{tabular}{c|c|c|c|c}
\hline \multicolumn{2}{c|}{ The hour get wet by high tide } & Exposed & Age \\
\hline $\begin{array}{c}\text { at the lowest } \\
\text { part of the } \\
\text { growing area }\end{array}$ & $\begin{array}{c}\text { at the highest } \\
\text { part of the } \\
\text { growing area }\end{array}$ & $\begin{array}{c}\text { at the middle } \\
\text { line of the } \\
\text { growing area }\end{array}$ & hours & of moon \\
\hline $17: 30$ & $18: 20$ & $(17: 55)$ & $\begin{array}{c}6 \text { hrs. } \\
10 \text { mins. }\end{array}$ & 5.3 \\
\hline $06: 40$ & $08: 00$ & $(07: 20)$ & $\begin{array}{c}(6 \text { hrs. } \\
10 \text { mins. })\end{array}$ & 7.3 \\
\hline
\end{tabular}

to the time when high tide passes over the same line.

* Tide Tables vol. 1 in 1964 : pp. 40-42, published by the Maritime Safety Board of Japan. 
mentioned tide levels of the habitats. In Text-fig. 1, a zone between two straight lines, each of which shows the upper or lower limit of the tide levels of the habitats, is a growing area of $U$. conglobata and the intervals between two intersections of the middle line of this zone and the tide curves in a high tide interval show the hours during exposure.

In August*, the hours during exposure was about $10 \mathrm{hrs}$. $10 \mathrm{mins}$, the longest range in this month on August 8th, new moon day, about 7 hrs., the shortest range was measured on August 16th, first quarter day. In January*

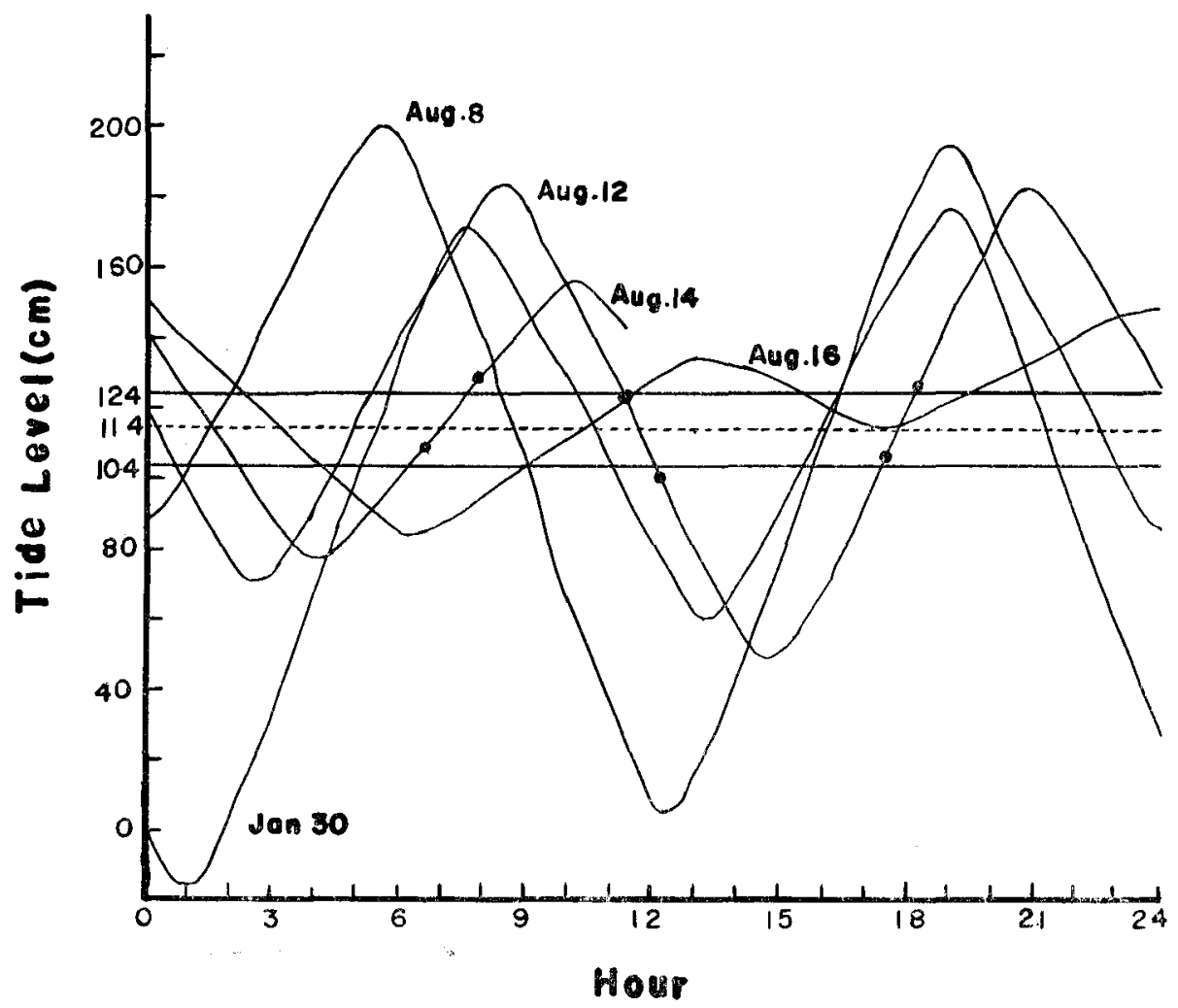

Text-fig. 1. Showing tide levels of both the upper and the lower limits of the growing area of Ulva conglobata and tide curves in 1964.

Straight lines show both the upper and the lower limits of the growing area whose middle line is dotted. Black spots show the hours surveyed.

\footnotetext{
* Atomospheric temperature at the station of the Seto Marine Biological Laboratory at 9 o'clock A. M. in January and August, 1964 are as below. Jan. mean $9.07^{\circ} \mathrm{C}$, maxim. $18.3^{\circ} \mathrm{C} ; 19.8^{\circ} \mathrm{C}$ (afternoon), minim. $4.8^{\circ} \mathrm{C} ; 2.1^{\circ} \mathrm{C}$ (night). Aug. mean $29.09^{\circ} \mathrm{C}$, maxim. $31.8^{\circ} \mathrm{C} ; 34.6^{\circ} \mathrm{C}$ (afternoon), minim. $25.3^{\circ} \mathrm{C} ; 23.8^{\circ} \mathrm{C}$ (night).
} 
they were about 13 hrs. 20 mins. on January 30th, full moon day.

In fact, the hours during exposure are variable owing to the condition of the sea. Generally speaking, however, $U$. conglobata grows in the area that is exposed even in the shortest range. This alga, moreover, must stand against such severe conditions as of cold nights in January or of hot daylight in August.

Swarmers and their development: In April 1963, it was observed that fourciliated swarmers were liberated from two individuals. In 1964 the writer investigated the liberation of four-ciliated swarmers from 18 individuals on April 13th and those from 35 individuals on August 13th, notwithstanding the materials were collected from different parts of the same growing area. Copulation-tests were tried with swarmers of seven optional individuals in the last case, but they did not copulate each other at all. Thus the writer concluded that these swarmers were not gametes, but zoospores.

The zoospore is elongate pear-shaped, $(3-5) \mu \times(7-12) \mu$ in size and has four cilia at the anterior end and an eyespot in the posterior part (Text-fig. $2 \mathrm{~A}$, B). As soon as zoospores are liberated from fronds, most of them swim to reach the photo-negative bottom of water. But swarmers from some individuals swim to reach the photo-positive surface of water at first and then to the photo-negative bottom finally.

Observations of the development of zoospores were made mainly on those materials collected on April 13th and August 13th, 1964. Within about five hours after liberations, zoospores became to cease their motions, to fasten to substratum, to lose their cilia, and round in shape and finally surrounded by cell membranes. At this stage their size were about $7 \mu$ in diameter (Text-fig. $2 \mathrm{C}, \mathrm{D}$ ). After several days their size increased to become $12-15 \mu$ in diameter, but eyespots contrarily became smaller and smaller and finally disappeared. At this stage single pyrenoid was distinctly visible (Text-fig. 2 E, F). Afterwards, most of spores began to germinate upwards and divided into two cells by a plane parallel to the surface of substratum or oblique one (Text-fig. 2 G-I, Plate XI 1, 2). With repeats of such transverse cell-divisions, they developed upwards from substratum and became simple filaments which consisted of a single row of cells (Text-fig. $2 \mathrm{~J}-\mathrm{M}$, Plate XI 3). When sporelings became about eight-cell stage, longitudinal cell-divisions took place at lower part of a filaments and most of filaments were covered with partly swollen membranes (Text-fig. $2 \mathrm{~N}$ ).

Basal cells of a filament simultaneously repeated their cell-divisions to all directions horizontally on the same plane to form a discoid holdfast which increased in size according as the erect portion grew up (Text-fig. 2 M-P, Plate XI 4-6). Sometimes the basal cells became polyhedral and fastened firmly to substratum by means of hyaline secretion (Text-fig. 2 L, Plate XI 3). 
In two weeks, the erect filaments reach $120 \mu$ in height and longitudinal cell-divisions progress from lower parts of filaments to upper ones. And the cell arrangement become actinomorphic in cross section. In three weeks the

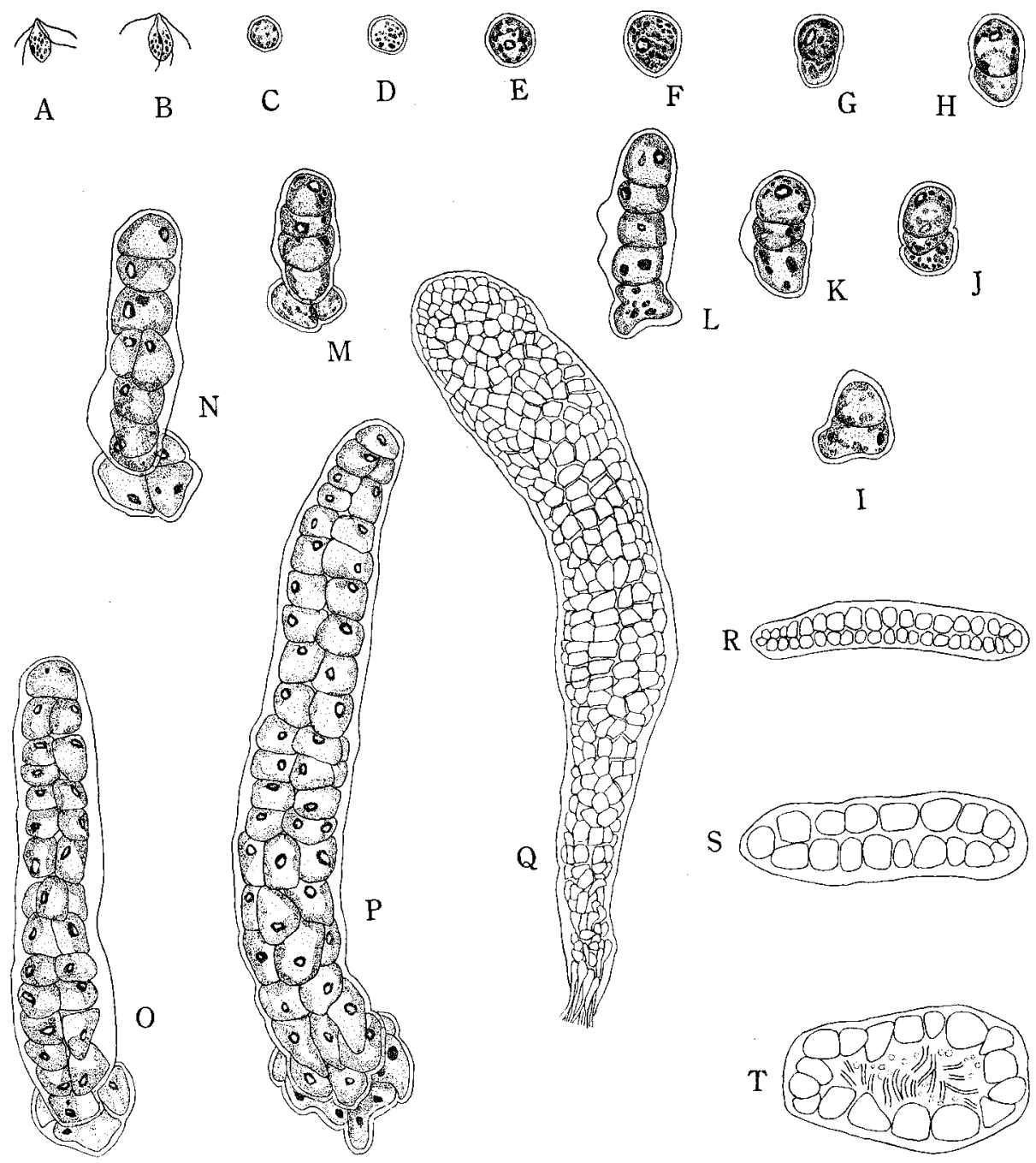

Text- fig. 2. Development of zoospores of Ulva conglobata KJELlman.

A, B, zoospores. C, D, one day old. E, F, four-day sporelings with clearly visible pyrenoid. $\mathrm{G}$, beginning of upward elongation. H, two-cell stage. I, elongation of basal cell on a slide-glass. J, three-cell stage. $\mathrm{K}$, same stage with partially swollen membrane. L, eightday sporeling whose basal cell shows a polyhedral shape. $M$, six-cell stage, cell-division of the basal cell on a slide-glass. $\mathrm{N}$, beginning of longitudinal cell-division. $\mathrm{O}$, fourteenday sporeling $\mathrm{P}$, twenty-one day sporeling, cells near basal part are beginning to change into rhizoidal cells. Q, one month old sporeling whose shape is cylindrical. $\mathrm{R}-\mathrm{T}$, cross views of sporelings. $\mathrm{A}-\mathrm{D} \times 500, \mathrm{E}-\mathrm{P} \times 470, \mathrm{Q} \times 125, \mathrm{R} \times 90, \mathrm{~S}-\mathrm{T} \times 200$. 
lower parts of filaments become cylindrical, looking like sporelings of Enteromorpha (Text-fig. 2 Q, T ; Plate XI 7, 8).

On the other hand, when filaments reach about $150 \mu$ in height, cells near the basal parts grow to issue rhizoids downwards and then cells nearest to them in the upper parts successively become rhizoidal cells (Text-fig. $2 \mathrm{P}, \mathrm{Q}$, Plate XI 7-9). Those rhizoids are all elongate toward the substratum, never shooting out from the filament surface, but covering a primary discoid holdfast and finally become to function as a permanent holdfast (Plate XI 8,9).

Repeating cell-divisions longitudinally and always having no cavity within, the cyrindrical filaments grow to be compressed without increasing their thickness at all. When the sporelings grow to be about $800 \mu$ in height, they expand both toward margins and apices at the same time retaining the structure of compressed two-cell layers (Plate XI 10, 12). The sporelings of $1.5-1.7 \mathrm{~mm}$ in height are cyrindrical at their basal parts whose component cells consisted of a circular row of cells containing many fibrous rhizoids or other structures within, which can be investigated on the cross section of the fronds. Contrary to this, however, in upper parts, the compressed structure is already completed even at their 18-cell stage in cross section (Text-Fig. 2 R-T).

Thus two-cell layered membranaceous structure of a frond of $U$. congrobata is completed (Flate XI 12).

After six months from the start of the culture, sporelings that developed on slide-glasses grew to be $1.5-1.7 \mathrm{~cm}$ in height, and these young fronds became already to be identical in appearance with natural adult plants (Plate XI 13).

\section{Discussion}

K. Fujtyama (1950) reported that fronds of Ulva congrobata collected on the coast in the vicinity of the Marine Biological Station of Tokyo University at Misaki, Kanagawa Prefecture, liberated gametes that were $(2.5-4) \mu \times(5-10) \mu$ in size between the end of July and the beginning of September, while zoospore were $(3.2-5) \mu \times(6-12) \mu$ in size and their liberation occurred between the end of August and the beginning of October. She also reported that both kinds of swarmers had two cilia and there were no difference in morphological characters between them.

So far as the present studies concerned, though a good deal of matured fronds were examined, gamete liberation could never be observed at Shirahama. Zoospores observed at Shirahama agreed with those reported by $\mathrm{K}$. Fujiyama merely in size, but differed from her results in the following two points, namely, (1) zoospore liberation occurred from earlier period and con- 
tinued in longer period than those described in her report, (2) they had four cilia.

These differences may supposedly be resulted from the difference between two quite remote habitats, but they should be inquired hereafter.

The developments of the membranaceous species in the Ulvaceae have hitherto been already studied by several investigators. In Japan, Y. YAmadA \& E. SAito (1938), working on Ulva pertusa and Enteromorpha linza from Muroran, Hokkaido, clarified that swarmers of both species repeated the transverse cell-divisions at first and developed into a simple filament of a few cells, one of which formed primary rhizoid, and then longitudinal cell-divisions took place to form sporelings issuing secondary rhizoids.

S. ARASAKI (1946) obtained results just similar to the above regarding Ulva lactuca, $U$. pertusa and E. linza from Ise- and Mikawa-bay.

The life-history of the genus Letterstedtia was studied by M. СHinara (1935) on L. japonica from Shimoda, Shizuoka Prefecture in Japan, and also by M. A. Pocock (1958) on L. instignis from Salt Vlei and Waterloo Bay in South Africa. These algae showed too, the same type of the initial development with Ulva and Enteromorpha mentioned above.

Y. YAMADA \& E. SAITo added in their report that sporelings of $U$. periusa often consisted of cells of nearly equal size and without primary rhizoids. M. Chinara described the same fact on L. japonica as an exceptional case, too. C. Bliding (1933) of Sweden, studied the development of E. linza in the vicinity of Zoological Station of Kristenberg and reported similar facts as mentioned above, but he described the attachment organ of sporelings as "Haftscheibe" beside its illustrations.

Comparing with these reports, the results of the writer's developmental siudies of $U$. conglobata are generally similar to those of other membranaceous species in the Ulvaceae. Regarding the development of attachments, U. conglobat a attaches to the substratum by discoid holdfast at first. After filaments grow upwards to some length, rhizoids are issued secondarily from the lower parts of filaments. These facts agree quite well with C. BLIDING's on E. linza and also with exceptional cases in the observations by Y. YAMADA \& E. SaIto on $U$. pertusa and by M. ChiHara on L. japonica.

It was not yet described satisfactorily in what way a filamentous sporeling became a membranaceous frond. But in the present study the writer observed that an Enteromorpha-shaped filamentous sporeling grew to become wider gradually by repeating longitudinal cell-divisions successively, thus they become to be compressed. This result suggests that membranaceous species of the Ulvaceae may all develop through the Enteromorpha-shaped sporeling. 


\section{Summary}

1) The writer has carried out cultural experiments and some field observations of Ulva conglobata at Shirahama in 1963 and 1964.

2) Fronds grow all the year round on the intertidal zone of rocky shores, forming a growing area that is $104 \mathrm{~cm}$ to $124 \mathrm{~cm}$ wide in tide level and exposed more or less even in the shortest range of tide.

3) This alga can stand against such severe conditions as night cold in January or hot daylight in August.

4) The writer collected materials in April, June and August. He always found nothing but zoospores, though the materials were collected from different parts in the same growing area.

5) Zoospore has four cilia and an eyespot, $(3-5) \mu \times(7-12) \mu$ in size.

6) After a zoospore becomes standstill, its first cell-division takes place on a plane parallel or oblique to the surface of substratum and then forms an erect filament from the first step of its development.

7) Basal cells of a filament repeat their cell-divisions horizontally on the same plane to form a discoid holdfast. But afterwards rhizoids are issued from the lowest parts of the erect body and become to be the parmanent holdfast, covering the discoid holdfast.

8) With the longitudinal cell-divisions in the erect body, cells are arranged actinomorphic in cross section and then the erect body becomes cylindrical, looking like sporeling of Enteromorpha. This result suggests that membranaceous species of the Ulvaceae may all develop through the Enteromorpha-shaped sporeling.

9) The upper parts of cyrindrical erect body grow to be compressed, without increasing their thickness, but expanding toward margins. And the sporeling becomes a frond which consists of two-cell layered structure.

10) Sporelings developed on slide-glasses to $1.5-1.7 \mathrm{~cm}$ in height. These young fronds became to be identical in appearance with natural adult plants.

\section{Acknowledgement}

The writer wishes to express his hearty thanks to Prof. Hiroyuki Hirose of Kobe University, who gave him a kind guidance and helpful advices, moreover who revised the manuscript cordially. He is also greatly in debted to Dr. Takasi Tokiona and Prof. Huzio Utinomi of the Seto Marine Bilogical Laboratory who gave him many facilities during the present studies, and many thanks, too, to Prof. Seibin Arasaki of Tokyo University who gave him many valuable suggestions. The writer expresses his gratitude to $\mathrm{Mr}$. Chûichi ArAga of Seto Marine Biological Laboratory who gave him many 
facilities in collecting materials, and also to Mr. Torao YамAмото who was very kind in showing him important facts. Also his thanks are due to Mr. Kiheiji Inoue, directer of the Suma Aquarium, and to colleagues there, especially to Dr. Ryônosuke Okuno, Messrs. Masao Nishiguchi and Hiroshi Амiмото, who were very kind to bring materials to Kôbe.

\section{REFERENCES}

ARASAKI, S. 1946. Studies on the swarmers and their development in Ulvaceae and Monostro. maceae. Seibutsu, $1(5 / 6): 285-286$. (in Japanese)

Bliding, C. 1933. Über Sexualität und Entwicklungs bei der Gattung Enteromorpha. Svensk Bot. Tidskr., 27 (2) : 235.

Chinara, M. 1953. On the life-history of Letterstedtia japonica Holmes. Jour. Jap. Bot., 28 (7) : 1-8. (in Japanese)

Fujiyama, K. 1950. On the life-history of the Ulva conglobata KJellm. Bot. Mag. Tokyo, 63 (749) : 222-223. (in Japanese)

Pocock, M. A. 1959. Letterstedtia insignis ALEschoug. Hydrobiologia, 14 (1) : 37-52.

SuTo, S. 1960. On a method of laboratory culture of the laver (Porphyra tenera KLELLM.). The Aquiculture, 7 (3):7-8. (in Japanese)

UTINOMI, H. 1958. Horizontal distribution of intertidal communities on rocky shores around the Tanabe Bay (Preliminary report). Rec. Oceanogr. Works in Japan. Special No. $2: 54$.

YAMADA, Y. and SAITO, E. 1938. On the some culture experiments with the swarmers of certain species belonging to the Ulvaceae. Sci. Papers Inst. Algolog. Res., Fac. of Sci., Hokkaido Imp. Univ., 2 (1) : 36-42.

\section{EXPLANATION OF PLATE XI}

1: Upward elongation of sporeling.

2: Two-cell stage sporeling.

3: Three-cell stage sporeling which is covered with swollen membrane.

4, 5: Sporelings which are fastened to slide-glass by discoid holdfast that consists of several cells.

6: Discoid holdfast that consists of many cells.

7, 8: Basal part of sporeling where many rhizoids are issued. Frond shows yet cylindrical structure.

9: Showing rhizoids that cover discoid holdfast underneath.

10: Fourty-day sporeling.

11: An parent specimen whose zoospores were used in the present cultural experiment. (collected on August 13th)

12: Two-month sporelings.

13: Four-month young fronds which are growing on a slide-glass.

14: An adult fresh plant which was collected in the field.

Magnification $\cdots \times 450$ for $1-3,5,9 ; \times 420$ for $4 ; \times 300$ for $6 ; \times 100$ for 7,$8 ; \times 45$ for 10 ; $\times 15$ for 12 ; and ca. $1 / 2$ for $11,13,14$. 
Publ. Seto Mar. Biol. Lab., XIII (2), 1965

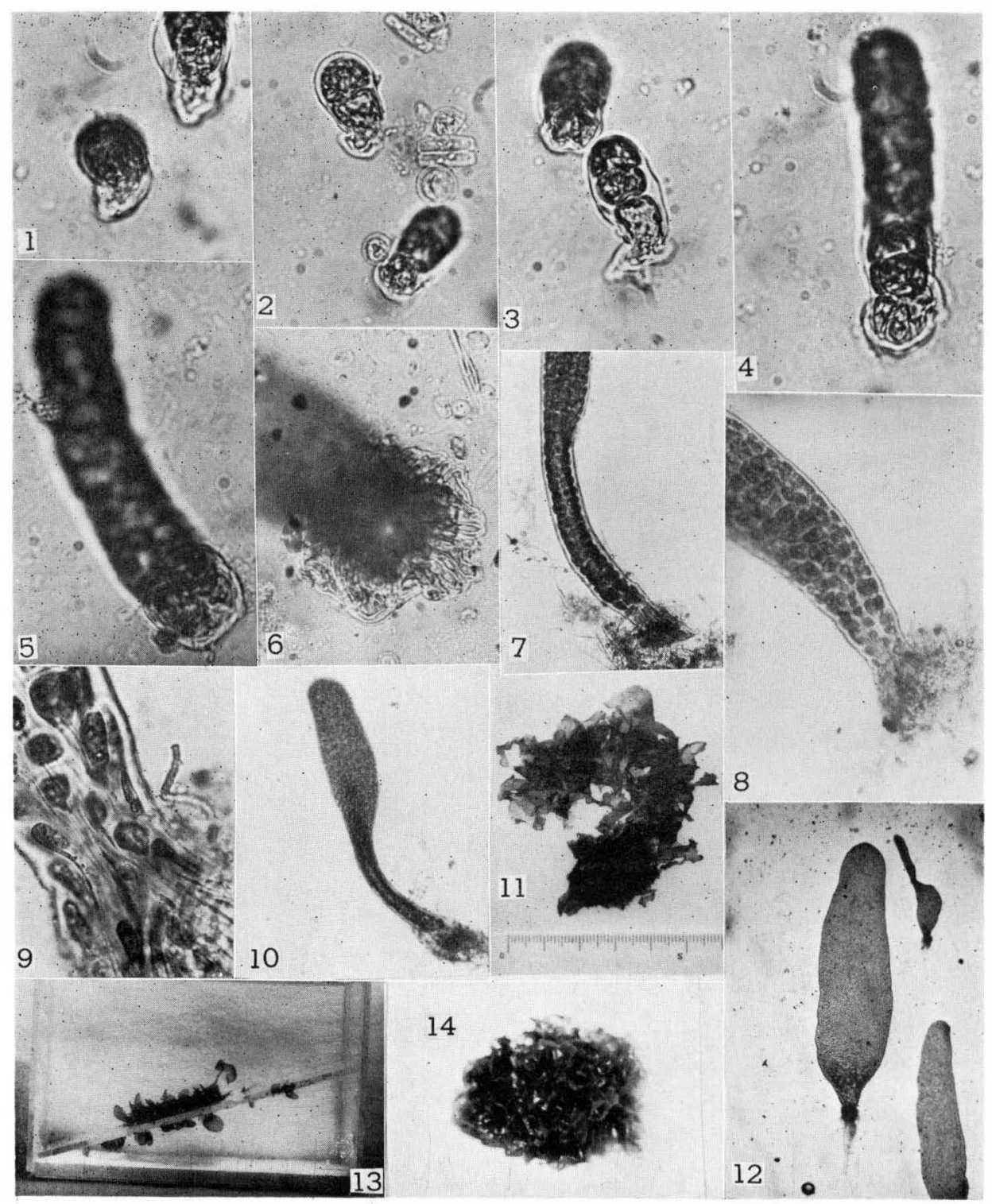

K. Yoshida ; Swarmers of Ulva conglobata, 